\title{
SUSTAINABLE MARKETING IN FASHION INDUSTRY \\ - GREEN IS THE NEW BLACK
}

\author{
Saša Virijević Jovanović \\ Dragan Doljanica ${ }^{2}$
}

DOI: https://doi.org/10.31410/ERAZ.S.P.2019.149

\begin{abstract}
The undeniable economic importance of the fashion industry has opened many research questions that have become the subject of relevant scientific institutions worldwide. Starting from the fact that the fashion industry is one of the few that has made constant growth in the past decade, it is challenging to continue its growth in the future, but on a sustainable basis. The paper analyzes the concept of modern fashion from the aspect of economy and its effects on the environment. With the current pace of production and consumption of fashion products, the industry faces the threat caused by the neglect of the environment and excessive use of resources. It is calculated that more than $\$ 500$ billion of value is lost every year due to clothing underutilization and the lack of recycling. This situation is unfavorable not only for society and the environment, but also for fashion companies taking into account the cost of resources, which will jeopardize the profitability. The core priorities for immediate implementation in fashion industry are supply chain traceability, combating climate change, efficient use of resources and secure work environments. Therefore, this research tends to emphasize the main obstacles that fashion industry will face toward its sustainable development in future as well as to explore the possible solutions.
\end{abstract}

Keywords: sustainable development, fashion industry, fast fashion, sustainable fashion, Pulse Score of the fashion industry.

\section{INTRODUCTION}

$I^{\prime}$ f we look at the history of fashion, we can conclude that fashion styles have been the most obvious indicator of intercultural exchange for centuries. The emergence of fashion product created the need for marketing in this industry whose task is to adapt the product to national market features, providing at the same time something new, different, creative, special and unique.

The processes of deregulation and trade liberalization, the emergence of economic integrations, such as the EU, the development of technology have affected the trends in the fashion market, which has become a major global business. However, in addition to the visible economic achievements, the strong development of the fashion industry has also brought concerns related to its negative effects on the environment. Measuring the influence of the fashion industry has provided the data that confirm the importance of sustainable development in this area.

The following data illustrate only one part of the environmental concerns that refer to fashion business:

- The total greenhouse gas emissions from textile production amount to 1.2 billion tons annually. [1]

- The fashion industry is projected to use $35 \%$ more land for fibre production by 2030 an extra 115 million hectares that could be left for biodiversity or used to grow crops to feed an expanding population.[2]

\footnotetext{
$1 \quad$ Faculty of Applied Management, Economics and Finance, Jevrejska 24, Belgrade, Serbia
}

2 Faculty of Applied Management, Economics and Finance, Jevrejska 24, Belgrade, Serbia 
- The apparel and footwear industries generated between 5 and 10\% of global pollution impacts in 2016.[3]

- Water used by the fashion industry today amounts 79 billion cubic meters.

- Only $20 \%$ of clothing is recycled, most of which turn into low-quality clothes due to the use of inadequate technology.[4]

\section{FASHION - THE BUSINESS, CULTURAL AND ENVIRONMENTAL PHENOMENON}

The term fashion represents popular styles in various spheres of human activity, in every period of history. Merriam Webster Dictionary defines the term as a popular way of dressing during a certain time and within a particular group of people. [5] Fashion can also be regarded as an extraordinary art, in which designers are artists who create. The modern term „fashion” means to construct, shape or make. Therefore, design and creation are important components of fashion. [6] The designer's essence is crucial and it can be seen in all fashion products.

The development of fashion through history has been documented in various fields such as: architecture, art, cosmetics, music, economics, management, politics, sociology, technology, media, service industry, philosophy, religion, sports, etc. Therefore, when studying fashion, one should bear in mind that it is an interdisciplinary field that connects the economic, cultural, creative, religious and artistic context. Fashion as a way of dressing represents a cultural phenomenon, and it is shaped depending on social, moral and religious norms. Accordingly, the awareness of the fashion brand has a different meaning in different cultures and countries.

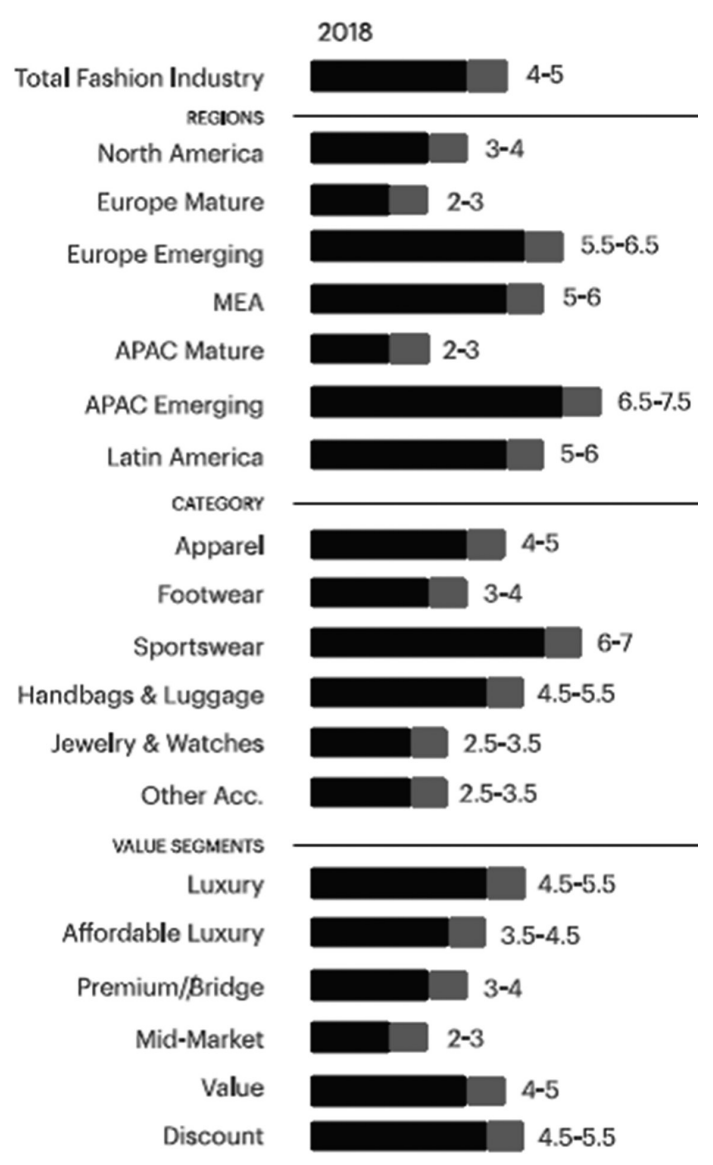

Figure 1: Fashion industry sales growth by region, category, and segment, $2018 \%$ [9] 
In recent decades, the fashion industry has grown into a prosperous business, causing to become a topic for researchers dealing with its impact on the economic flows in the world. According to consultants McKinsey the global apparel, fashion and luxury industry has achieved growth in the market during the last 15 years, outstripping even high-growth sectors like technology and telecommunications. [7] Figure 1 demonstrates fashion industry sales growth by region, category and segment during 2018. The highest sales growth $(6,5-7,5)$ is recorded in Asia-Pacific emerging countries, with an expectation to continue its performance in 2019. [8] The analysis of value segment performance in fashion industry showed that sportswear category had the highest sales growth in 2018, followed by the sector of handbags and luggage.

The global fashion market is characterized by strong competition among a large number of companies. The fashion business brings to successful ,players” a lot of money, but at the same time the industry is known for its often changes as well as the high risk for new entities that appear on the market. Another consequence of the fashion globalization is the geographical distribution of textiles, clothing and footwear, which has changed significantly over the past 30 years. In addition, the globalization has led to the relocation of production from Europe and North America to Asia and developing countries. However, 2018 was marked by trade policies and barriers, which also reflected on the global fashion market. These tendencies are particularly pronounced in US, where the fashion industry accounts for 6 percent of imports but pays 51 percent of tariff receipts.[10]

Besides the economic and cultural context of fashion, scientific attention in recent years has been focused on the issues of sustainable development. There are many topics that are raised in relation to the sustainable development of the fashion industry, but the most important are the following:[11]

- The development of standards and practices for designing fashion products that can be easily reused or recycled;

- Investing in the development of new fibres, which will reduce the negative effects on the environment;

- Managing innovations that will contribute to reducing CO2 emissions;

- Encouraging consumers to be ecologically conscientious;

- Support the development of recycling technologies;

- Setting high environmental standards and mechanisms for better control along the supply chain.

When it comes to sustainable development of fashion, the first association is overproduction and the problem of recycling. It is estimated that 400 billion square meters of textiles are produced each year globally and 60 billion square meters end up as cutting floor waste. With the current production and consumption of fashion products, the industry faces the threat caused by the neglect of the environment and excessive use of resources. However, if the fashion industry successfully solves environmental and social issues, it is estimated that by 2030 the world economy would achieve 160 billion euros. [12]

The issues of excessive production of fashion products are most often associated with the concept of fast fashion that is applied by profitable companies like Inditex and H\&M. However, it is evident that manufacturers of luxury fashion products, such as Burberry for example, are also facing this problem. During 2017 the public was shocked by the famous British label which decided to destroy unsold clothes, accessories and perfume worth $£ 28.6 \mathrm{~m}$ in order to protect its brand. [13] 


\section{THE FAST FASHION - GROWTH ON SUSTAINABLE BASIS}

'Fast fashion' is a term used to describe a fashion business model that involves increased numbers of new fashion collections every year, quick turnarounds and often lower prices. [14] Fast or instant fashion began its development during the 1970s. The essence of business philosophy that fast fashion companies implement is that they are constantly monitoring the latest trends from the catwalks in order to quickly turn them into final products and deliver them to customers at affordable prices.

A company that is associated with the initiation of this phenomenon in the fashion market is Inditex, the most successful fashion company in the world with economic profit about 4bn dollars in 2017. [15] Inditex's most recognizable brand is Zara, which needs only two weeks to develop a new product and places it in the stores. If we explore the business concept of the company, we can conclude that Zara is a vertically integrated retailer. This means that it has better control along the supply chain, since the company itself designs, produces and distributes independently. Another important feature of fast fashion model is that Zara is a fashion imitator and focuses its attention on understanding consumer behaviour and current tendencies in the market.

However, although the philosophy of fast fashion companies is a good case study which shows how to increase the profitability, at the same time it is seen as a business model that encourages over-consumption and generates excessive waste. The fashion designer Phoebe English has accused the business model of 'fast fashion' for making the sector a "monstrous disposable industry". [16]

The development of fast fashion on a sustainable basis may at first glance seems like a contradiction, but it is still possible. The solution lies in a circular economy which would ensure that clothes are made from safe and renewable materials, resulting in turning old clothes into new. [17] The idea of circular fashion was launched by the Ellen MacArthur Foundation in 2016, and presented at the World Economic Forum in Davos. In May 2017, Make Fashion Circular was originally launched as the Circular Fibres Initiative, at the Copenhagen Fashion Summit. Today, under the auspices of this initiative, the leaders of the fashion industry (Burberry, Gap Inc., H\&M Group, HSBC, NIKE Inc., and Stella McCartney as Core Partners) are gathered, in order to define new sustainable rules for doing business as well as the new paradigm of a fashion industry. The main strains of circular fashion are: [18]

- The safe and healthy material input which will allow cycling and avoiding negative impacts during the production, use, and after-use phases;

- Increase utilization of purchased fashion products;

- Radically improve recycling;

- Make effective use of resources and move to renewable inputs.

\section{THE FASHION SUSTAINABILITY PERFORMANCE}

Raising awareness of the negative effects of the fashion industry has created the need to closely monitor the performance of its companies and products.

\subsection{The pulse score of the fashion industry}

The Pulse Score was developed in order to measure and track the sustainability of the global fashion industry on key environmental and social impact areas. The Score is based on the Higg Index which is developed by the Sustainable Apparel Coalition. It represents a set of tools that measure and score a company or product's sustainability performance. [19] The Index has three 
modules: brand, facilities and product. [20] The brand module measures the degree of transparency, environmental/social impact tracking as well as fashion brands' collaboration with facilities. The facilities module deals with environmental and social measures applied by fashion-industry suppliers. The product module refers to design processes in order to find the best solution regarding design and material choices in coordination with sustainability.

The Pulse Score of the fashion industry represents measures on a scale from 1 to 100, where scores below 20 are defined as weak, and scores higher than 70 are strong. In the past few years, the fashion industry's Pulse Score improved from 32 to 42 (Figure 2), which is significant improvement. The overall Pulse Score gap from 42 to 100 indicates the size of the industry's opportunity to create new value for society and individual businesses. [21]

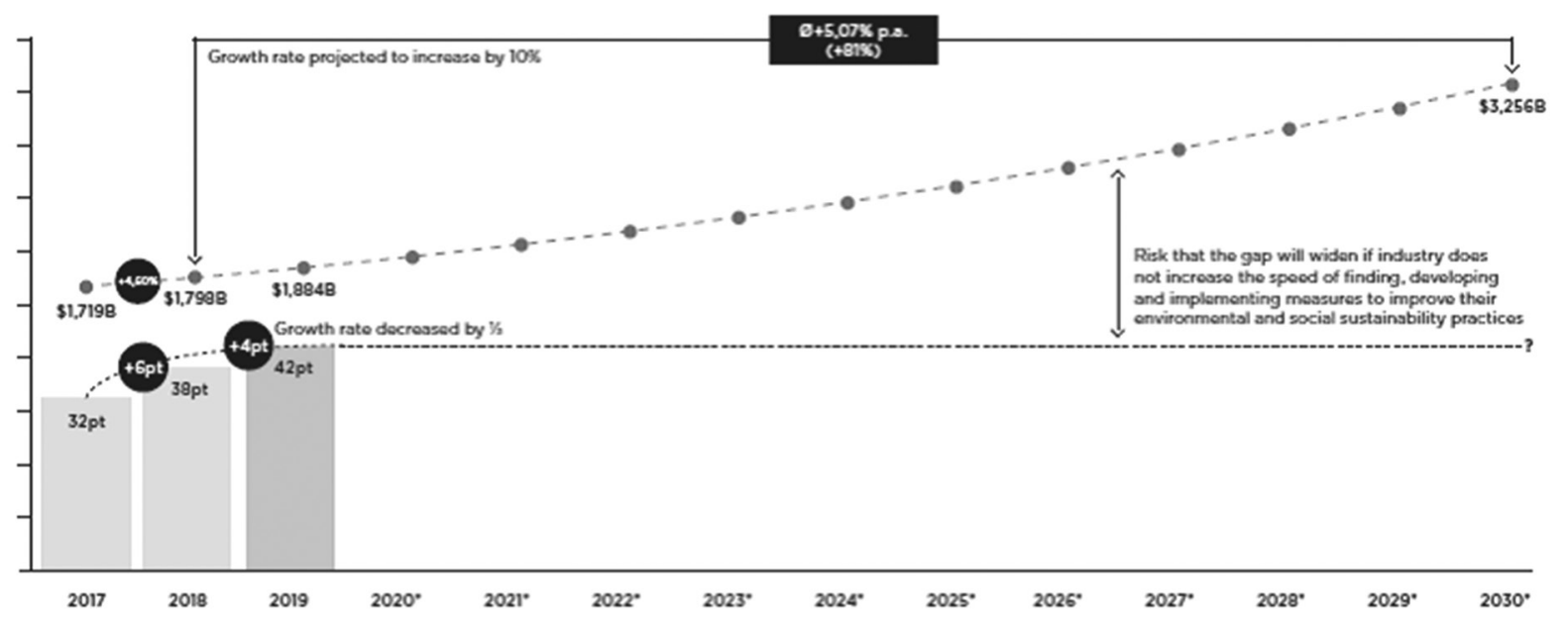

Figure 2: The 2019 Pulse Score growth rate from 2017 [22]

\subsection{Sustainability targets in fashion industry}

According to Global Fashion Agenda fashion brand CEOs have important influence on sustainable development in the industry due to the fact that their decisions affect the entire value chain. Therefore, the CEO Agenda 2019 emphasizes two sections of actions towards the sustainability: four core priorities for immediate implementation, and four transformational priorities for fundamental change in the longer term. The core priorities for immediate implementation are the following: [23]

1. Supply chain traceability, which is in direct correlation with the implementation of circular business model. This process begins with the raw material extraction, continues with the material processing, manufacturing, product packaging, transporting and disposal. According to the Agenda, 12.5 percent of the global fashion market, including big brands like Nike, Adidas, Levi's and Gap, have signed up to 2020 sustainability targets, which include publishing lists of all the suppliers producing for them.

2. Combating climate change. It is necessary to monitor and measure the fashion impact on climate change during the entire value chain. According to Quantis (2018) the Dyeing and Finishing, Yarn Preparation and Fiber Production life cycle stages appear to be the 3 main drivers of the industry's global pollution impacts. It is also interesting to look at the findings of the Carbon footprint of clothing in the UK which demonstrate that extraction and washing are the processes of the biggest concerns (Figure 3).

3. Efficient use of water, energy and chemicals. The fashion industry is known for its negative impact as a dominant user of water and energy. Cotton is one of the thirstiest fibers 
in fashion. [25] One kilogram of cotton used in production of a shirt and pair of jeans - can take as much as 10,000-20,000 litres of water to produce. [26] Another important problem is the utilization of chemicals like fertilizers, pesticides and dyes. The use of fertilizers is particularly evident in the cotton production as well, which uses nitric and phosphoric fertilizers whose overuse leave its trace in water.

4. Secure work environments. A particular challenge for the sustainable development of the fashion industry are issues related to working conditions, labour exploitation, employees' rights, gender discrimination and child abuse. Regarding all of these questions the fashion industry is often accused to be supporter of modern slavery. The Global Slavery Index's 2018 report, published by the Walk Free Foundation, emphasizes that $\$ 127.7$ billion worth of garments at risk of including modern slavery in their supply chain are imported annually by G20 countries, a group of nations which account for 80 percent of world trade. [27]

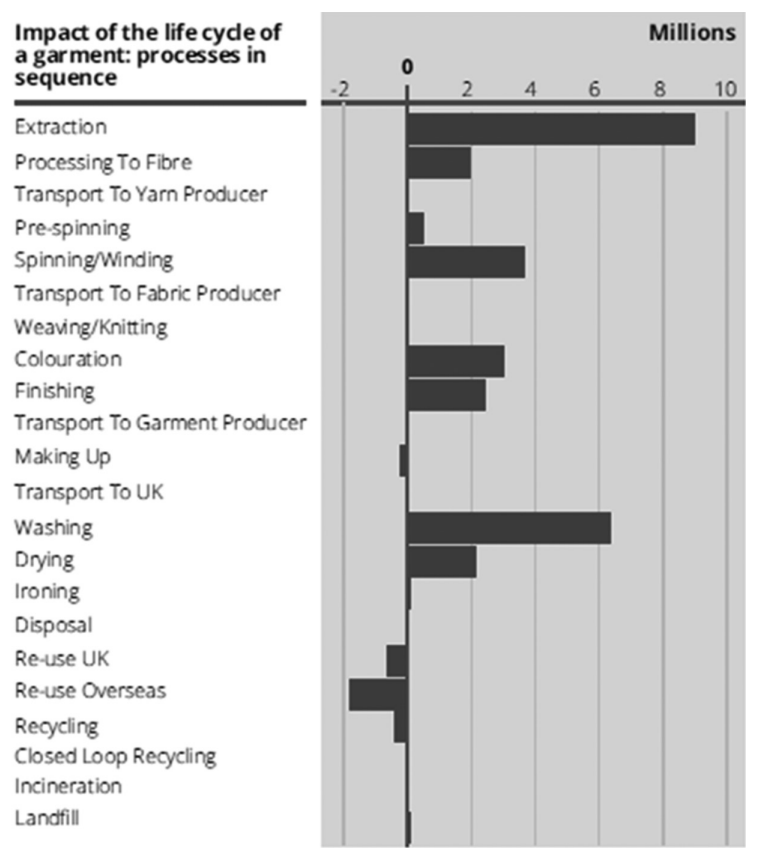

Figure 3: Carbon footprint of clothing in the UK (t CO2e) in 2016, by process [24]

The other section refers to transformational priorities for fundamental change which include:

1. Decreasing the negative effects of existing fibers and developing new innovative, more sustainable fibers.

2. Circular fashion system that will empower recycling and re-use of products as well as utilization of purchased fashion products.

3. Promotion of better wage systems.

4. Fourth industrial revolution based on digitization of processes along the value chain.

Realization of stated goals will help achieve the $€ 160$ billion annual opportunity for the world economy. [28] Therefore, nowadays we can find many examples of successful sustainable fashion. Some of them are the following:

- Adidas has made one million shoes from recycled ocean plastic. [29] Another revolutionary innovation, developed by this brand is the DryDye technology that allows dyeing without water use.

- Famous brand Stella McCartney was a pioneer who fought against the use of animal fur in the fashion industry. After many years of fighting, Stella McCartney traced the 
path for fur-free fashion which is today accompanied by the well-known luxury brands, such as: Chanel, Jean Paul Gaultier, Burberry, Versace, John Galliano, Furla, DKNY, Michael Kors, Gucci, Giorgio Armani, Phillip Lim, Diane von Furstenberg, St. John and The Kooples. Stella McCartney has also made important steps towards the fashion revolution, by introducing sustainable materials such as leather made from mushrooms, bioengineered spider silk and others.

- The Italian fashion house Salvatore Ferragamo, which is recognizable for its luxury items, began producing lines of scarves and dresses with beautiful prints, using silk blends made largely from recycled fruit. This green innovation was created through cooperation with Orange Fiber, which deals with the recycling of orange peel. Orange Fiber was founded by two Italian entrepreneurs who recognized the potential for eco-innovation by finding that the juice industry in Italy produces 700,000 tons of orange peel every year, which ends at landfills. [30]

- Regarding the issues of supply chain traceability brand leaders such as Zara and Tesco have taken responsibility for the negative effects of their production processes. In order to achieve a better sustainability, they are testing the wastewater from the factories, looking for better solutions and building relationships with the workers in Asia and developing countries, where they have relocated their productions. [31]

\section{SUSTAINABLE FASHION FROM THE CONSUMER POINT OF VIEW}

Fashion globalization has opened many issues related to the cultural and social dimensions that shape the behaviour of contemporary consumer, who is becoming more aware of sustainability problems that occur in the industry. A research launched by Boston Consulting Group has showed that $75 \%$ of consumers in the five countries surveyed view sustainability as extremely or very important. The survey also pointed out that $38 \%$ of consumers are ready to switch from their preferred brand to another because it credibly stands for positive environmental. [32] This very fact shows the importance of the sustainable development in fashion, seen through the eyes of consumers, who are ready to break their long-standing loyalty to a brand that does not behave environmentally conscientious. Similar findings came from Nielsen survey which demonstrated that $81 \%$ of global respondents feel strongly that companies should help improve the environment. [33]

Thus, the issue of sustainable development went from the margins of the fashion industry to the mainstream. From the fashion consumer point of view "the green has become the new black". Sustainability is today one of the important criteria on the basis of which consumers make their purchasing decisions. According to Fashion Revolution, the survey of 5000 people aged 16-75 in the five largest European markets, including Germany, United Kingdom, France, Italy and Spain showed that when choosing a fashion brand to buy, consumers said it is important for brands to: [34]

- publish how products are sustainable on the packaging (72\%),

- explain what products are made from on the packaging $(77 \%)$,

- make it clear where they source materials, ingredients and components from and who manufactured the product (77\%),

- share detailed information about wages and working conditions for people in its global supply chain $(66 \%)$, and

- provide information about how they apply socially responsible practices (70\%),

- provide information about how they apply environmentally responsible practices (74\%). 


\section{CONCLUSION}

The main challenge that fashion industry faces on its path towards the sustainable development is to find the balance between environment, society and economy. This is a very demanding task that should connect all the stakeholders: owners, managers, fashion designers, engineers, researchers, workers, institutions, as well as the consumers, who are also responsible for the utilization of fashion products.

Recent surveys taken by Boston Consulting Group and Nielsen showed that modern consumers see the sustainability as extremely or very important. Therefore, sustainable conscience of fashion brands has strong impact on the buying behaviour. Taking into account such consumer views and demands, fashion brands have begun a good practice of applying the concept of sustainability. In the past few years, the fashion industry's Pulse Score improved from 32 to 42 , leaving the gap at 58 points as an indicator that it is still far from sustainable. According to Global Fashion Agenda there are four core priorities for immediate implementation that fashion brands should make: supply chain traceability, combating climate change, efficient use of resources and secure work environment. These priorities are related to the issues such as recycling and re-using of fashion products, the concept of circular fashion, value chain management, environmental protection as well as social justice and labour rights that are often in question when it comes to production in fashion.

\section{REFERENCES}

[1] Fashion Industry (2018) UN Pursue Climate Action for Sustainable Development, INITIATIVE / 22 JAN, 2018, https://unfccc.int/news/fashion-industry-un-pursue-climate-action-for--sustainable-development

[2] WRAP (2017) Valuing Our Clothes: the cost of UK fashion, file://C :/Users/User/Documents/fashion/valuing-our-clothes-the-cost-of-uk-fashion_WRAP.pdf

[3] Quantis (2018) Measuring Fashion: Insights from the Environmental Impact of the Global Apparel and Footwear Industries, https://quantis-intl.com

[4] BCG (2017) Puls of the Fashion Industry, pp.11

[5] https://www.merriam-webster.com

[6] Easey M. (2009) Fashion marketing, John Wiley \& Son, Oxford, pp. 5

[7] McKinsey \& Company, (2015) Creating value in fashion: How to make the dream come true

[8] McKinsey and Company, Business of Fashion (2019) The State of Fashion, pp.97

[9] McKinsey Global Fashion Index (MGFI)

[10] McKinsey and Company, Business of Fashion (2019) The State of fashion, pp.31

[11] Remy N., Speelman E. and Swartz S. (2016) Style that's sustainable: A new fast-fashion formula, www.mckinsey.com

[12] BCG (2017) Puls of the Fashion Industry, pp.2

[13] Burberry burns bags, clothes and perfume worth millions, https://www.bbc.com/news/ busines, 19 July 2018

[14] House of Commons Environmental Audit Committee (2019) Fixing fashion: clothing consumption and sustainability, Sixteenth Report of Session 2017-19, House of Commons, UK, pp.6

[15] McKinsey Global Fashion Index (MGFI) 
[16] House of Commons Environmental Audit Committee (2019) Fixing fashion: clothing consumption and sustainability, Sixteenth Report of Session 2017-19, House of Commons, UK, pp.6

[17] Make Fashion Circular, https:/www.ellenmacarthurfoundation.org/our-work/activities/ make-fashion-circular

[18] Ellen MacArthur Foundation, A new textiles economy: Redesigning fashion's future, (2017, http://www.ellenmacarthurfoundation.org/publications), pp.23

[19] https://apparelcoalition.org/the-higg-index/

[20] Global Fashion Agenda \& The Boston Consulting Group (2017) Pulse of The Fashion Industry, pp. 28

[21] Seara J, Boger S, Hase C, Berlepsch V, and Deichmann S. (2018) Sustainability Is Good Business for Fashion, https://www.bcg.com/publications/2018/sustainability-good-business-fashion.aspx

[22] Lehmann M., Arici G., Boger S. and others (2019) Pulse of the fashion industry 2019 update, Global Fashion Agenda, Boston Consulting Group, and Sustainable Apparel Coalition pp.1

[23] Tärneberg S., Lehmann M., Eder- Hansen J., Kruse E. and Chalmer C. (2019) CEO Agenda 2019, Global Fashion Agenda

[24] WRAP, Valuing Our Clothes: the cost of UK fashion, July 2017, file://C:/Users/User/Documents/fashion/valuing-our-clothes-the-cost-of-uk-fashion_WRAP.pdf pp.12

[25] House of Commons Environmental Audit Committee (2019) Fixing fashion: clothing consumption and sustainability, Sixteenth Report of Session 2017-19, House of Commons, UK, pp.29

[26] WRAP (2017) Valuing Our Clothes: the cost of UK fashion

[27] https://www.globalslaveryindex.org/

[28] How Innovation and Collaboration Can Accelerate Sustainability in Fashion, https:// www.bcg.com/publications/2017/retail-how-innovation-collaboration-accelerate-sustainability-fashion.aspx

[29] Europe Consumer Trends 2019, http://reports.mintel.com

[30] http://orangefiber.it/en/

[31] How to fashion a better world, https://www.greenpeace.org, 12 July 2018,

[32] Lehmann M., Arici G., Boger S. and others (2019) Pulse of the fashion industry 2019 update, Global Fashion Agenda, Boston Consulting Group, and Sustainable Apparel Coalition, pp.11

[33] Global consumers seek companies that care about environmental issues, 11-09-2018, https:/www.nielsen.com/ssa/en/insights/news/2018/global-consumers-seek-companies-that-care-about-environmental-issues.html

[34] Fashion revolution, Consumer survey report, November 2018, https://www.fashionrevolution.org/resources/consumer-survey/ 